\title{
Public Support for Wetland Restoration: What is the Link With Ecosystem Service Values?
}

\author{
Samantha S. K. Scholte ${ }^{1}$ Maya Todorova ${ }^{2}$ - Astrid J. A. van Teeffelen ${ }^{1}$. \\ Peter H. Verburg ${ }^{1}$
}

Received: 10 July 2015 / Accepted: 17 February 2016/Published online: 7 March 2016

(C) The Author(s) 2016. This article is published with open access at Springerlink.com

\begin{abstract}
Fostering public support for wetland restoration is essential for long-term sustainable management and use of wetland areas. This paper explores the socio-cultural dimension of wetland restoration, by looking at the importance of wetland ecosystem services for different user groups. We try to better comprehend such values by evaluating the awareness people have of ecosystem services and the direct benefits people obtain from the ecosystems in their surroundings. In addition, we study how the values people assign to ecosystem services are related to wetland restoration attitudes. We identified four perspectives towards wetland restoration, which could partially be explained by corresponding values for ecosystem services: an eco-centric, a cultural, an economic and a negative perspective. To gather public support for wetland restoration it is important to take into account the different motivations people have to support such initiatives.
\end{abstract}

Keywords Socio-ecological systems · Nature conservation · Ecological restoration $\cdot$ Attitudes $\cdot$ Awareness

Electronic supplementary material The online version of this article (doi:10.1007/s13157-016-0755-6) contains supplementary material, which is available to authorized users.

Samantha S. K. Scholte

samantha.scholte@vu.nl

1 Environmental Geography Group, VU University Amsterdam, De Boelelaan 1085, 1081 HV Amsterdam, The Netherlands

2 WWF Danube-Carpathian Programme, Ruse, Bulgaria

\section{Introduction}

Wetlands are of key importance to biodiversity conservation and important providers of a range of goods and services such as water quality improvement, flood abatement and carbon sequestration (Zedler and Kercher 2005; de Groot et al. 2012). Yet, wetland areas suffer vastly from overuse of resources, eutrophication and pollution, disconnection from parent rivers by dike construction, water abstraction for industrial and domestic use, and land reclamation (Junk et al. 2012; van Asselen et al. 2013). In Europe, $50 \%$ of the wetlands have been converted to urban and agricultural lands (Gumiero et al. 2013). International agreements and EU legislation aim to prevent the further degradation of wetland ecosystems, e.g. the Ramsar convention, the EU Water Framework Directive and the Habitats Directive. Although such regulations have contributed towards wetland conservation and restoration, wetland areas are still susceptible to drainage and reclamation, especially when major economic interests are at stake (Čížková et al. 2011; Verhoeven 2014). Gathering public support for wetland restoration is essential to ensure social commitment towards sustainable use and management of restored wetlands.

A challenge for gathering public support for wetland restoration is that restoration may undermine local income, as a result of limited access to the natural resources, or conversion of farmland to natural land cover (Naughton-Treves et al. 2005). Ecological restoration initiatives are often part of an international framework that aims to achieve regional and/or global conservation targets (such as the Aichi Biodiversity Targets and EU biodiversity targets), for which local people may pay the price (Adams et al. 2010; Kari and KorhonenKurki 2013). In the conservation literature this tension has been referred to as the 'parks versus people' debate, where the protection of global biodiversity through so-called fortress conservation is at one end of the spectrum and a focus on 
improving local livelihoods is at the other end (Southworth et al. 2006; Minteer and Miller 2011). Bringing these two groups together often proves difficult, as ecological restoration often involves competing rather than complementary goals (McShane et al. 2011). To protect nature restoration and conservation areas from resource depletion or destruction, restrictions on natural resource use are necessary. Because of such restrictions, people have been displaced or denied access to the resources, threatening their rights and livelihoods (Brockington and Wilkie 2015).

An additional challenge for wetland restoration is that people commonly have negative associations with wetland ecosystems. Wetlands are perceived as useless, strange, difficult to access and unattractive (Meindl 2000; Nassauer 2004). For this reason, the goods and services provided by wetlands are often not recognized by society. In addition, although the importance of public engagement for ecological restoration has long been recognized, the communication of restoration benefits from science to the wider public has had limited success (Groffman et al. 2010). To tackle this issue, an ecosystem service (ES) approach is increasingly advocated. The ES framework aims to inform the public about the benefits humans receive from nature, by portraying explicit links between a wide range of (wetland) ecosystem functions and human well-being (Costanza et al. 1997; Daily 1997; de Groot et al. 2002).

The dominant narrative of the ES framework (as shown in the ES cascade depicted in Fig. 1) has focused much on the supply of ESs (Raymond et al. 2013; Comberti et al. 2015), portraying how ecosystems, through different ecological functions, provide services and goods that people appreciate and rely on (de Groot et al. 2010; Haines-Young and Potschin 2010). As such, the ES framework has commonly been used as an awareness raising tool, with the underlying assumption that once people become aware of ESs, they will be more willing to support nature conservation. The importance people assign to ecosystems and their related goods and services, however, is not only influenced by knowledge, but also depends on how people interact with ecosystems (Daw et al. 2011; Scholte et al. 2015). Given the supplybased focus in ES research, there is limited understanding of how values for (wetland) ESs are shaped by the way people perceive, depend on and use the ecosystem (Asah et al. 2014). To contribute to this research gap, we investigate how the importance local beneficiaries assign to wetland ESs, i.e. values for ESs, can be understood by looking at their knowledge of wetland ecosystems, i.e. awareness of ESs, and the way people depend on and use wetland ecosystems (Fig. 1). In addition, we aim to understand how values for ESs are related to attitudes towards wetland restoration.

We explicitly distinguish between the awareness of ESs and the socio-cultural values for ESs, because these two do not necessarily coincide. A person may be aware of the flood regulating capacity of a wetland as a benefit to others, but not consider it important for his or her own livelihood. As such, we define awareness of ESs as the ability of an individual to recognize the ESs delivered by an ecosystem and we define value for ESs as the importance people assign to ESs. Our focus is on a nature conservation area at the Lower Danube in Bulgaria, where recently several wetlands have been restored. We explore the perceptions, values and activities of local farmers, fishermen and residents to gain a better understanding of why local users are motivated to support wetland restoration efforts. By exploring the different perspectives towards wetland restoration this paper provides insights that can be used to better manage wetland conservation and restoration areas.

\section{Methods}

\section{Study area}

Persina Nature Park (Persina) is the only nature conservation area along the Bulgarian part of the Danube River, covering an area of 21,762 ha. It was established in 2001 and is situated along the Lower Danube River in Bulgaria (Fig. 2). The Lower Danube comprises the last $860 \mathrm{~km}$ of the $3000 \mathrm{~km}$ long Danube River, which is one of the main watersheds in Europe. There are two municipalities within the boundaries of Persina: Belene (10,318 inhabitants) and Nikopol $(9,305)$. The main economic activities in the area are agriculture and fishing. Most of the area is state-owned (60\%), while the rest of the area is owned by farmers. Small scale farms are most prominent, but are often owned and managed by big leaseholders.

Along the Lower Danube $75 \%$ of the floodplains have been cut off from the river (Ebert et al. 2009), mostly in the 1960 's to make room for agricultural lands, fishponds and hybrid poplar plantations (Schneider 2010). Recognizing the loss of important hydrological and ecological functions, such as the mediation of pollutants and the increased probability of a flood event (Hulea et al. 2009), the World Wide Fund for Nature (WWF) secured an agreement between the governments of Bulgaria, Romania, Ukraine and Moldova to establish a 'Lower Danube Green Corridor' (LDGC) in 2000. The aim of the LDGC project is to:

'make the Lower Danube a living River again, connected to its natural flooding areas and wetlands, reducing risks of major flooding in areas with human settlements and offering benefits both for local economies - fisheries, tourism - and for the ecosystems along the river' (WWF 2010).

As part of the LDGC, Persina was established and designated as a protected area, falling under the NATURA 2000 network in Europe. The most important ecological asset of Persina is the Belene Island complex, which consists of 19 islands and was designated as wetlands of international 
Fig. 1 Conceptual diagram of the studied factors within the ES framework. Adapted from de Groot et al. (2010) and Haines-

Young and Potschin (2010)

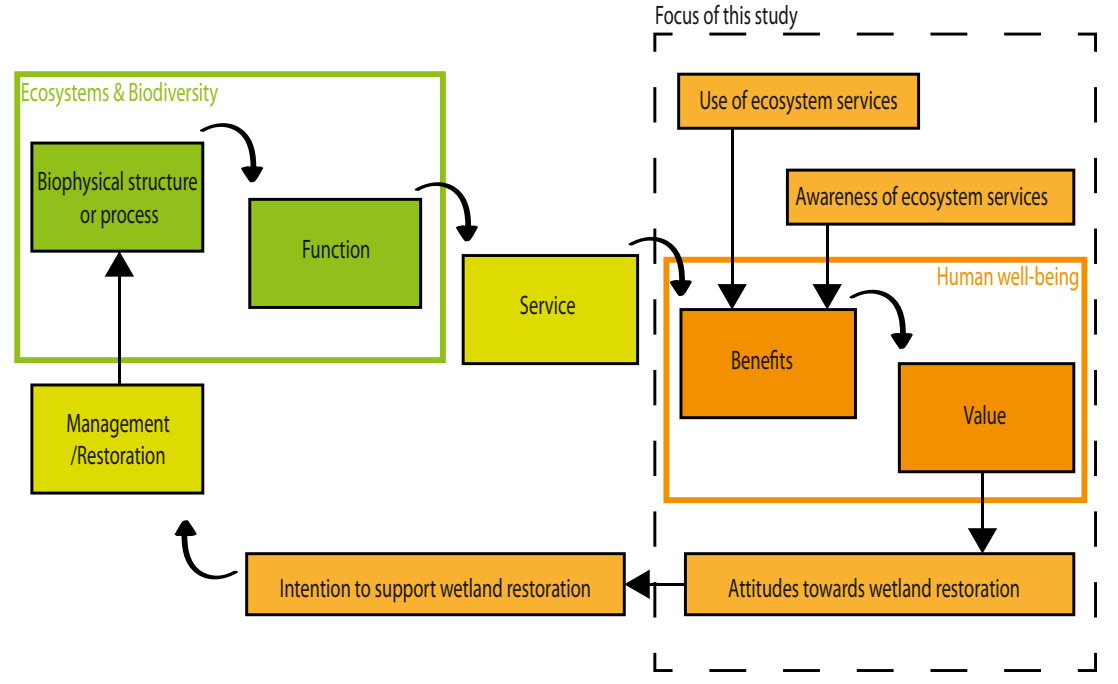

importance under the EU RAMSAR Convention. The largest island of this complex, Persin Island, which is also the largest island along the Danube in Bulgaria, was one of the pilot sites for wetland restoration. The eastern part of the island has been restored into a natural wetland in 2004. An important aim for the WWF, who co-manages this restoration project, was to raise awareness about the benefits provided by wetlands and gather public support by local communities for wetland

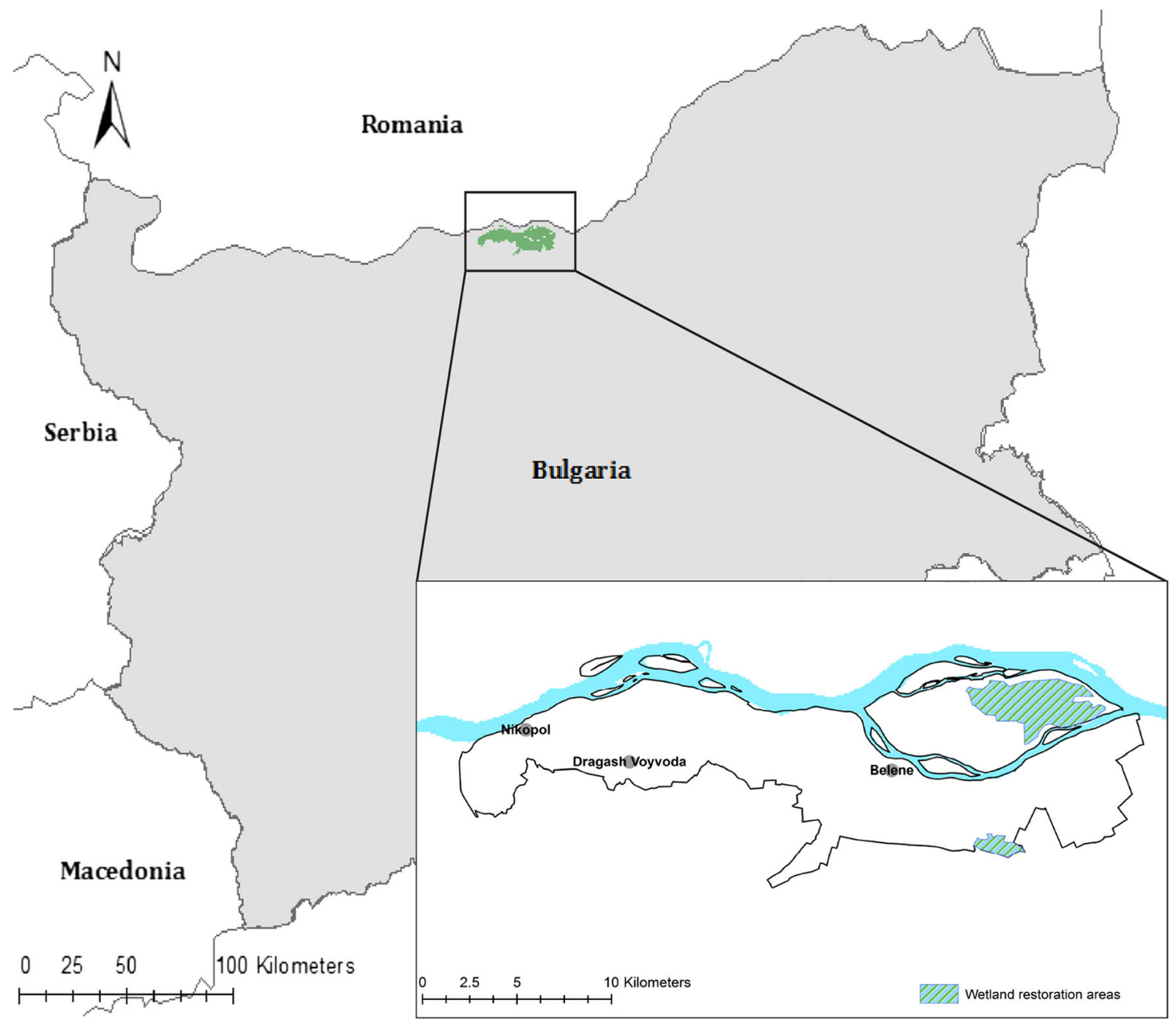

Fig. 2 Location of the study area 
restoration. It is in this particular context that this study has taken place.

\section{Wetland types}

There are different types of wetlands, each type having their own distinct characteristics. Dobbie and Green (2013) demonstrated that people do not see wetlands as a homogeneous group, but distinguish between different types of wetlands by characteristics of water and vegetation: respondents in their study classified wetlands as 'grasslands', 'treed grasslands', 'wetlands with emergent vegetation','wetlands with open water', 'arid (water) scapes' or 'treed wetlands'. We address three specific wetland types that are prominent in our study region: (a) treed wetlands, i.e. riparian forests, (b) wetlands with open water, i.e. marshes, and (c) grasslands, i.e. meadows. These wetland types also correspond to classes that can be found under the Ramsar Classification System for Wetland Type, specifically 'Freshwater tree-dominated wetlands' (riparian forests, class Xf), 'Permanent freshwater marshes' (marshes, class Tp), and 'Seasonally intermittent freshwater marshes/pools, including seasonally flooded meadows' (meadows, class Ts) (Ramsar Convention Secretariat 2010).

\section{Data collection and questionnaire design}

We conducted structured face to face interviews amongst three different user groups in Persina: farmers, fishermen and local residents of Nikopol and Belene in April and May 2014. We recruited four local interviewers to interview the respondents using a pre-formulated questionnaire. We pre-tested the questionnaire in March 2014. We contacted farmers and fishermen with the support of local authorities, specifically the Agricultural Service and the Executive Agency for Fisheries and Aquaculture. We approached all farmers who applied for yearly funding at the Agricultural service between the period of April and May 2014 and requested their participation. The Executive Agency for Fisheries and Aquaculture provided us with contact details of all fishermen associations in the area. We approached local residents at public places, e.g. parks, restaurants and shops, in Belene and Nikopol. This lead to a total of 105 interviews. Three respondents did not complete the interview, leaving a total of 102 completed questionnaires. For an overview of the demographic characteristics of our sample: see Appendix (Table 5).

The questionnaire was divided into five sections, addressing 56 questions about: the use of ESs, awareness of ESs, socio-cultural values for ESs, attitudes towards wetland restoration and socio-demographics. For the questionnaire we identified a list of 14 ESs. We pre-selected ESs based on the Millennium Ecosystem Assessment (MEA) classification of ecosystem services (Millennium Ecosystem Assessment 2005) and adapted this list with input from stakeholders working at local environmental organizations, who expressed which ESs they thought were most relevant for wetland ecosystems in Persina. The final ESs included in this study were provisioning (food, materials, medicines and biomass for energy), regulating (climate regulation, maintaining water quality, ground water retention, soil erosion control and flood control) and cultural (environmental education, tourism, recreation, aesthetic values and existence values for biodiversity).

The first section of the questionnaire was aimed at gaining information on the respondents' familiarity with and activities undertaken in Persina. In the second part we asked respondents which ESs they thought were provided by Persina and asked them to indicate which wetland type could be related to these ESs. We used pictograms that visualized the ESs to avoid scientific terminology (see supplementary material). Each respondent had to choose from the 14 ESs a maximum of 5 ESs that they thought were supplied by (a) Persina in general, (b) riparian forests, (c), marshes and (d) meadows. The different wetland types were each represented by 2 photos (see supplementary material). For each component, i.e. Persina and the three wetland types, we also asked respondents whether they could think of any other benefit that was not depicted on the cards. In addition we asked the respondents if they had any negative associations and if so, to specify them.

In the third part of the questionnaire respondents had to choose a maximum of 5 ESs that they thought were most important for their personal well-being (i.e., self-oriented values) and for the well-being of all people living in Persina (i.e., other-oriented values), assuming that all could be equally supplied by Persina.

In the fourth part of the questionnaire, we tested the specific attitude towards wetland restoration in Persina. We first showed respondents a map of Persina on which wetland restoration projects were indicated. Respondents were firstly asked whether they were aware of these wetland restoration projects. Consequently respondents had to evaluate 7 statements about wetland restoration in Persina. The statements were evaluated using a 3-point Likert scale. In the final part of the questionnaire, respondents were asked to provide information regarding their age, place of residence, occupation, income and education.

\section{Data analysis}

We first defined multi-response sets for the awareness and valuation variables. The multi-response sets were consequently used for further analysis by calculating frequency tables and chi-square statistics to analyze differences between user groups and awareness of the ESs supplied by the different wetland types. To link ES values to attitudes towards wetland restoration we calculated a value variable that reflected how many ESs in each ES category, i.e. cultural, provisioning and regulating, the respondent had mentioned. Since the amount of services was not equal in all three ES categories, we corrected the value of each variable by dividing the amount of mentioned ESs by 
the total amount of ESs in each category. For instance if a respondent had mentioned one regulating service, the value was 1 divided by 5 , since 5 regulating services were considered. To each respondent we assigned a value for cultural ESs, regulating ESs, and provisioning ESs. Consequently, we standardized both the value variables and attitude variables and performed an exploratory principal component analysis (PCA) using a Promax rotation. We followed the Kaiser criterion (eigenvalue $>1$ ) to identify significant components. Finally, to identify how much each respondent within the user groups could be associated with each component, we created scatter plots based on the component scores.

\section{Results}

\section{Use of ESs}

\section{Farming and Fishing}

More than half of the farmers worked on a mixed farm, $27.3 \%$ worked on an animal farm and $21.2 \%$ worked on a crop farm (Table 1). The size of the farms differed substantially, but animal farms were much smaller (0.5-40 ha) than crop (2$400 \mathrm{ha})$ and mixed farms (1-1900 ha). The majority of the farmers $(71 \%)$ worked on farms smaller than 50 ha, which they fully owned, partially leased or fully leased. Farmers working on lands ranging from 100 to 1000 ha (20\%) owned only a very small proportion of this land. None of the fishermen said they could live entirely of fishing, and so many had taken on other jobs to sustain their livelihoods.

\section{Visiting Persina}

Of all respondents taken together, $12.7 \%$ never visited Persina Nature Park, $16.7 \%$ had visited Persina once, $25.5 \%$ had visited Persina a few times and $45.1 \%$ visited Persina often. Fishermen visited Persina most often outside work, while farmers visited Persina less often. The most popular recreational activity was walking and $7.8 \%$ of the respondents, only farmers and fishermen, also said they went hunting every now and then. Of all respondents, 24.6\% mentioned they went to Persina to collect food and/or materials. Four respondents mentioned they collected materials, mostly wood. Other respondents collected herbs and fruits $(11.8 \%)$ or fish $(11.8 \%)$.

\section{Awareness of ESs}

\section{Do People Recognize the ESs Provided by Wetlands in Persina?}

When asked whether they thought that Persina provided any of the depicted ESs, the respondents mentioned provisioning and cultural ESs the most, specifically provision of food and recreation (Fig. 3). Flood regulation was only mentioned once. Seven percent of the respondents had negative associations with Persina, which mostly had to do with mosquitoes, accessibility, and perceived degradation of the area.

When linking ESs to specific wetland types in Persina, cultural and provisioning ESs were mentioned the most (Fig. 3). Regulating services were not mentioned that often, but a few respondents did associate flood regulation and soil erosion control with marshes and riparian forests, whereas they did not mention these services when asked for ESs provided by Persina in general. Alternatively, several ESs were mentioned often when linked to Persina in general, but were mentioned less often when linked to specific wetland types: this was particularly the case for environmental education, tourism, recreation, and the provision of food.

There were significant differences between the awareness of ESs provided by meadows, mashes and riparian forests $\left(\chi^{2}=83.219, \mathrm{df}=29, p<0.05\right)$. Meadows were associated with the provision of medicine and food, more than the other wetland types. Biodiversity and water quality were mostly associated with marshes, and the provision of materials and recreation were mostly associated with riparian forests. Meadows were associated more with aesthetic quality than marshes and riparian forests. Twenty-two percent of the respondents had negative associations with marshes, mostly regarding the presence of mosquitoes. Two respondents associated marshes with a threat to floods. Ten percent of the respondents had negative associations with riparian forests, which surprisingly related most to a fear of flooding. In addition a few respondents mentioned that riparian forests were not easily accessible and that they are not properly managed. Two respondents had negative associations with meadows and they both mentioned improper management of the area.

\section{How are Knowledge of and Visits to Persina Related to the Awareness of ESs?}

As shown by previous results, most respondents were not aware of the regulating ESs provided by Persina. Since many regulating services are not visible (in contrast to the provisioning ESs) it may require additional knowledge to be aware of them. To see whether those who were aware of the regulating ESs may have had better (general) knowledge about Persina Park, we asked respondents several questions regarding their knowledge of Persina. Of all respondents, $80 \%$ had heard about Persina before and $75 \%$ knew that Persina had a protected area status. At the same time, however, only $37 \%$ had heard about the wetland restoration project at Persin island. We performed a chi-square test to see whether people who knew about the wetland restoration project, were also more aware of regulating ESs provided by wetlands in Persina, but found no significant results. 
Table 1 Use of ESs by different user groups. Values indicate percentages per user group

\begin{tabular}{lllll}
\hline Use of ESs & $\begin{array}{l}\text { Farmers } \\
(n=33)\end{array}$ & $\begin{array}{l}\text { Fishermen } \\
(n=24)\end{array}$ & $\begin{array}{l}\text { Residents } \\
(n=45)\end{array}$ & $\begin{array}{l}\text { Total } \\
(n=102)\end{array}$ \\
\hline
\end{tabular}

Work

Type of farm

$\begin{array}{ll}\text { Crop } & 21.2 \\ \text { Animal } & 27.3 \\ \text { Mixed } & 51.5\end{array}$

Percentage of income dependent on farming/fishing

$\begin{array}{lll}\text { Less than half } & 17.1 & 56.0 \\ \text { About half } & 28.6 & 20.0 \\ \text { More than half } & 17.1 & 24.0 \\ \text { All } & 37.2 & \end{array}$

Recreation \& collection of food/materials

Visit Persina Nature Park outside work

81.9

15.2

100

84.5

87.3

Once

36.4

16.7

17.8

16.7

2-5 times

20.8

20.0

25.5

More than 5 times

$30.3 \quad 62.5$

46.7

45.1

Visit Danube river and/or islands

$60.6 \quad 91.7$

82.2

77.4

Walking

$69.7 \quad 50.0$

60.0

60.8

Hunting

9.1

20.8

$-$

7.8

Collecting food/materials for own livelihoods

29.2

31.3

24.6

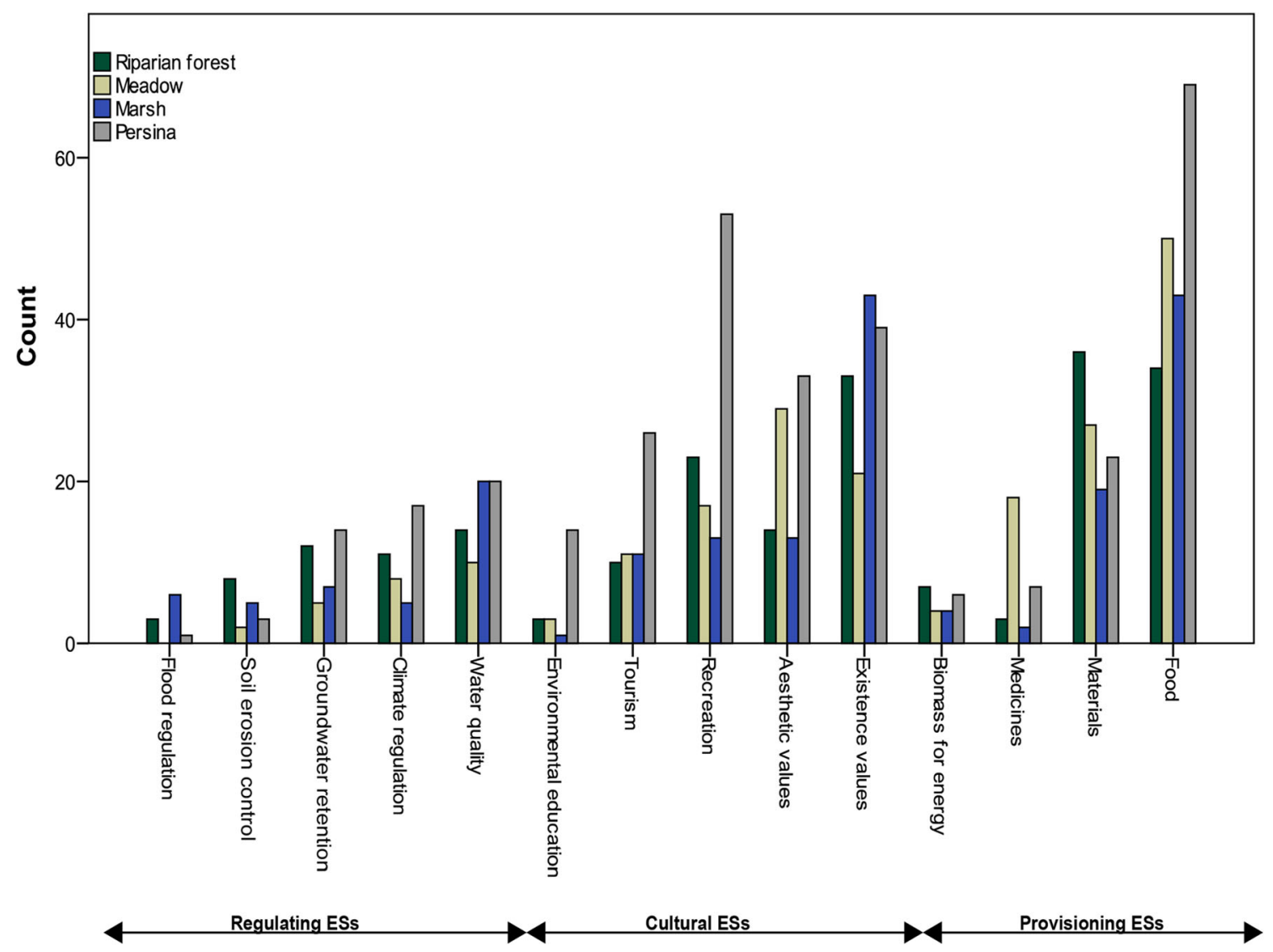

Fig. 3 The awareness of ESs expressed as the amount of times the ES was mentioned by all respondents for Persina as a whole and for each wetland type 
Respondents who visited Persina more often may also have been more aware of particular ESs provided by Persina. We therefore assessed several linkages between awareness of ESs and the visits people made to Persina: type of visits, frequency of visits and location of visits. We grouped all responses to each separate wetland type (i.e. marshes, meadows and riparian forests) into one larger variable, reflecting whether people had recognized any ESs for any of the wetland ecosystems in Persina. Since we studied a large number of ESs, we made a selection for further analysis based on the results in Section Do people recognize the ESs provided by wetlands in Persina?. From each category, i.e. cultural, provisioning, and regulating ESs, we selected the ES that was mentioned most for the wetland types: water quality, existence values for biodiversity and the provision of food.

Significant differences were found for all three ESs (Table 2). Respondents who visited Persina frequently, more often recognized water quality as an ES than respondents who visited Persina a few times or less, did. In addition, respondents who went walking in Persina or went to Persina to collect food were more aware of water quality than respondents who did not. Respondents who went to the Danube River during visits also recognized water quality more often than respondents who did not. Respondents who visited the Danube River also recognized the ability of wetlands to support biodiversity more often than respondents who did not visit the Danube river. Not surprisingly, respondents who collected food in Persina mentioned food as an ES more often than respondents who did not collect food.

\section{Values for ESs Provided by Persina}

To account for both self-oriented values and other-oriented values, the respondents were asked to value ESs first for their own personal well-being and consequently for the well-being of all residents living in Persina. Overall, differences between the two types of value were not significant $\left(\chi^{2}=9.958\right.$, $\mathrm{df}=14, p=0.765)$. For both self-oriented and other-oriented values, the provisioning of food and materials, recreation, existence of biodiversity, aesthetic values, and tourism were found to be the most important ESs (Fig. 4).

\section{Differences in Awareness and Values Between Different Users}

There were significant differences between user groups in their awareness of ESs (Table 3). Fishermen recognized food as an ES significantly more often than did farmers and residents. Fishermen also recognized materials as an ES significantly more than residents did. Farmers were significantly more aware of regulating ESs than residents, specifically water quality (Table 3).

Despite the higher awareness of water quality, farmers did not mention this ES significantly more often than residents when asked to indicate which ESs were most important for their personal well-being. Across all user groups, the cultural and provisioning ESs were found most important. Significant differences were found for biodiversity, which was more important to farmers than to residents. Provision of materials and food were both found most important by the fishermen. Although provisioning services were important for fishermen, they also assigned a lot of value to cultural ESs, specifically recreation. The most important cultural ESs for residents were recreation and aesthetic values.

\section{Links Between Values for ESs and Attitudes Towards Wetland Restoration}

Results from the PCA demonstrated four different perspectives on wetland restoration (Table 4). Four components with Eigen values larger than 1 were found, explaining $67.5 \%$ of the total variance (Kaiser-Meyer-Olkin measure of sampling adequacy, $\mathrm{KMO}=0.700$; Bartlett's test of sphericity, $\left.\chi^{2}=285.605, \mathrm{df}=45, p<0.001\right)$. The Promax component correlation matrix indicated a slight correlation $\left(\mathrm{r}^{2}=0,389\right)$ between the first and the second component.

The first component explained $32.5 \%$ of the variance and can be understood as supporting wetland restoration from a cultural perspective, emphasizing the importance of wetlands for human well-being, especially for the provision of cultural ecosystem services. Both the statement 'Wetlands are important for the local population' and 'Wetlands are important for
Table 2 Chi-square statistics $\left(\chi^{2}\right)$ for frequency, location and type of visits to Persina and awareness of wetland ESs

\begin{tabular}{llll}
\hline Visits to Persina & \multicolumn{2}{l}{ Awareness of wetland ESs } & \\
\cline { 2 - 4 } & Water quality & Biodiversity & Food \\
\hline Frequency of visits & $\mathbf{4 . 8 6 7 *}$ & 1.687 & 2.444 \\
Visits Danube river and/or islands & $\mathbf{3 . 2 1 7 ^ { * }}$ & $\mathbf{3 . 2 6 5}^{*}$ & 0.094 \\
Walking & $\mathbf{5 . 2 1 7 ^ { * * }}$ & 0.253 & 1.234 \\
Hunting & - & - & - \\
Collecting food & $\mathbf{5 . 0 7 4 * *}$ & 0.0008 & $\mathbf{6 . 5 7 5}^{* *}$ \\
\hline
\end{tabular}

For hunting the $\chi^{2}$ could not be calculated due to limited responses. These fields were left blank

*Significance level at $10 \%$, * Significance level at $5 \%$ 


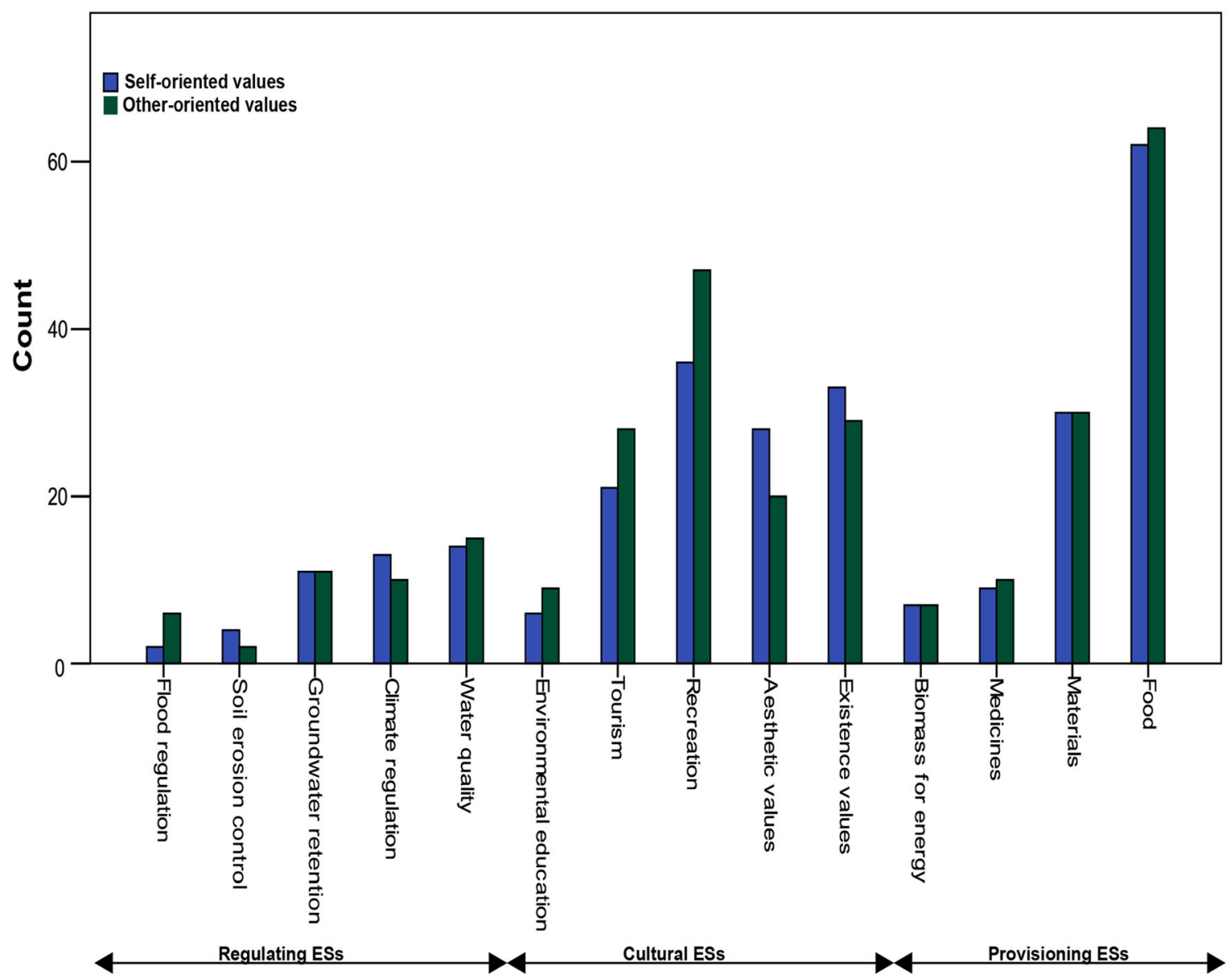

Fig. 4 The socio-cultural values for ESs expressed as the amount of times the ES was mentioned for personal well-being (self-oriented) and well-being of everybody living in Persina (other-oriented)

downstream communities' correlated positively with this component. The statement 'the restoration of wetlands limits the economic growth of this region' correlated negatively with this component, suggesting that wetland restoration and economic development do not necessarily conflict.

The second component explained $14.5 \%$ of the variance and can be explained as supporting wetland restoration from an eco-centric perspective, with a focus on the importance of wetlands for plants and animals. No correlation was found with any of the ecosystem service variables, which may indicate that this perspective can be understood as seeing a wetland as 'nature for itself', without making strong links with benefits for people. This is confirmed by the positive correlation of the statement "wetlands should not be drained for agricultural purposes".

The third component explained $10,5 \%$ of the variance and can be understood as viewing wetland restoration from an economic perspective. Appreciation of provisioning services correlated with this component, while appreciation of regulating services negatively correlated with this component. As the statements concerning the importance of wetlands did not strongly correlate (either positively or negatively) with this component, it is difficult to judge whether this component indicates a negative or positive attitude toward wetland restoration. The statement 'the restoration of wetlands limits the economic growth of this region' does not necessarily imply a negative attitude towards wetland restoration, but acknowledges that there is a trade-off between economic prosperity and wetland restoration.

The final component demonstrates a negative attitude towards wetland restoration. There was no correlation with appreciation for ESs, suggesting that a negative perspective may go together with low values for all ESs, i.e. seeing nature as providing no benefits.

Figure 5 shows that respondents are heterogeneously distributed across the four perspectives. Using a one-way ANOVA we tested for differences between the user groups for all components. No significant differences were found for component 2 and 4 . We did find significant differences between the user groups for component $1(\mathrm{~F}(2,99)=5.985$, $p<0.01)$ and component $3(\mathrm{~F}(2,99)=4.126, p<0.05)$. For component 1 , the Tukey post-hoc test revealed a significant difference between farmers and fishermen $(p<0.01)$ : whereas farmers had mostly negative scores for the cultural perspective, fishermen had mostly positive scores for the cultural perspective. For component 3, we found a significant 
Table 3 Percentages of people who recognized and valued each

\begin{tabular}{|c|c|c|c|c|c|c|c|c|c|}
\hline \multicolumn{5}{|l|}{ Awareness of ESs } & \multicolumn{5}{|l|}{ Values of ESs } \\
\hline & $\begin{array}{l}\text { Farmers } \\
(n=33)\end{array}$ & $\begin{array}{l}\text { Fishermen } \\
(n=24)\end{array}$ & $\begin{array}{l}\text { Residents } \\
(n=45)\end{array}$ & $\chi^{2}$ & & $\begin{array}{l}\text { Farmers } \\
(n=33)\end{array}$ & $\begin{array}{l}\text { Fishermen } \\
(n=24)\end{array}$ & $\begin{array}{l}\text { Residents } \\
(n=45)\end{array}$ & $\chi^{2}$ \\
\hline Regulating ESs & & & & & Regulating ESs & & & & \\
\hline Flood regulation & 3 & 0 & 0 & - & Flood regulation & 0 & 0 & 4.4 & - \\
\hline Soil erosion control & 0 & 4.2 & 4.5 & - & Soil erosion control & 0 & 0 & 8.9 & - \\
\hline Ground water retention & 18.2 & 8.3 & 13.6 & - & Ground water retention & 12.1 & 13.0 & 8.9 & - \\
\hline Climate regulation & 24.2 & 20.8 & 9.1 & 3.624 & Climate regulation & 18.2 & 8.7 & 11.1 & - \\
\hline Water quality & $30.3^{\mathrm{a}}$ & 25 & $9.1^{\mathrm{a}}$ & $6.117^{*}$ & Water quality & 9.1 & 21.7 & 13.3 & - \\
\hline Cultural ESs & & & & & Cultural ESs & & & & \\
\hline Environmental education & 15.2 & 4.2 & 18.2 & - & Environmental education & 6.1 & 0 & 8.9 & - \\
\hline Tourism & 21.2 & 29.2 & 27.3 & 0.522 & Tourism & 9.1 & 34.8 & 22.2 & 5.126 \\
\hline Recreation & 51.5 & 62.5 & 47.7 & 1.576 & Recreation & 24.2 & 52.2 & 35.6 & 4.039 \\
\hline Aesthetic values & 30.3 & 45.8 & 27.3 & 2.721 & Aesthetic values & 24.2 & 21.7 & 33.3 & 1.480 \\
\hline $\begin{array}{l}\text { Existence values of } \\
\text { biodiversity } \\
\text { Provisioning ESs }\end{array}$ & 48.5 & 25 & 38.6 & 3.252 & $\begin{array}{l}\text { Existence values } \\
\text { for biodiversity } \\
\text { Provisioning ESs }\end{array}$ & $46^{\mathrm{a}}$ & 39.1 & $20^{\mathrm{a}}$ & $6.016^{*}$ \\
\hline $\begin{array}{l}\text { Provision of biomass } \\
\text { for energy }\end{array}$ & 0 & 8.3 & 9.1 & - & $\begin{array}{l}\text { Provision of biomass } \\
\text { for energy }\end{array}$ & 0 & 17.4 & 6.7 & - \\
\hline Provision of medicines & 9.1 & 0 & 9.1 & - & Provision of medicines & 9.1 & 8.7 & 8.9 & - \\
\hline Provision of materials & 18.2 & $41.7^{\mathrm{a}}$ & $15.9^{\mathrm{a}}$ & $6.643 *$ & Provision of materials & 30.3 & $60.9^{\mathrm{a}}$ & $13.3^{\mathrm{a}}$ & $15.285^{* *}$ \\
\hline Provision of food & $63.6^{\mathrm{a}}$ & $91.7^{\mathrm{a}, \mathrm{b}}$ & $59.1^{\mathrm{b}}$ & $8.572 *$ & Provision of food & $60.6^{\mathrm{b}}$ & $91.3^{\mathrm{a}, \mathrm{b}}$ & $46.7^{\mathrm{a}}$ & $10.949 * *$ \\
\hline
\end{tabular}

ES Significant values indicate that there was a significant difference between, at least two of, the user groups

*Significance level at $5 \%$,* Significance level at $1 \%$. For some services the $\chi^{2}$ could not be calculated due to limited responses. These fields were left blank. Values marked with the same letter are significantly different (calculated through post-hoc pairwise comparisons, $p<0.05$ )

difference between fishermen and residents $(p<0.05)$ and farmers and residents $(p<0.1)$ : residents had lower scores for the economic perspective than did farmers and fishermen.

\section{Discussion}

\section{Linking use, Awareness and Valuation of ESs}

Across the entire sample, we found a low appreciation for regulating ESs and a higher appreciation for cultural and provisioning ESs. Agbenyega et al. (2009) suggested that regulating ESs may be overlooked because of the invisible character of these services. People may need better understanding of such services in order to appreciate them. Our results show that farmers mentioned water quality more often than the residents did. As farmers need some level of ecological knowledge to maintain their lands, thereby interacting with ecosystems in a different manner than residents do, they may indeed have a better understanding of the ecological functioning of an ecosystem. At the same time, however, our results demonstrate that despite the higher awareness of water quality as an ES, farmers did not place higher values on water quality than the residents. Regulating services are often not considered important because people do not see the end-benefit of such services or how they are relevant in their lives. An improved general awareness of ESs does not necessarily have to lead to a higher appreciation of ESs. Instead, use of and experience with the ecosystem may be more important for the appreciation of certain ESs (Setten et al. 2012; Pröpper and Haupts 2014).

The importance of provisioning ESs, especially the provision of food, is not surprising given the economic dependency of farmers and fisherman on the resources provided by Persina. An emphasis on the importance of the material benefits of an ecosystem is common in areas where social and ecological systems are tightly linked (Rönnbäck et al. 2007; Hartter 2010). This does not mean that immaterial benefits are disregarded or not considered important: our results show that cultural ESs were valued highly, by all user groups. This is in line with findings by Calvet-Mir et al. (2012), who studied home-gardens and found that, despite the importance of the provision of food, the cultural services, such as cultural heritage and aesthetic values, 'played a central role in explaining the societal importance attributed to home gardens' (p. 159). What is particularly apparent in our study is that farmers and fishermen, who had high values for provisioning services, also mentioned cultural ESs more often than residents. Residents placed the highest values on aesthetic quality of the landscape, but fishermen placed high values on recreation and tourism. In addition, farmers found the support of biodiversity 
Table 4 Four perspectives were identified linking attitude toward wetland restoration and values for ES categories. Loadings between -0.4 and 0.4 are excluded from the table

\begin{tabular}{|c|c|c|c|c|}
\hline Variables & $\begin{array}{l}\text { Cultural perspective } \\
(32,5 \%)\end{array}$ & $\begin{array}{l}\text { Eco-centric } \\
\text { perspective }(14,5 \%)\end{array}$ & $\begin{array}{l}\text { Economic } \\
\text { perspective }(10,5 \%)\end{array}$ & $\begin{array}{l}\text { Negative } \\
\text { perspective }(10 \%)\end{array}$ \\
\hline Wetlands are important for the local population & .769 & & & \\
\hline Wetlands are important for downstream communities & .748 & & & \\
\hline Value for cultural ESs & .740 & & & \\
\hline Wetlands should not be drained for agricultural purposes & & .824 & & \\
\hline Wetlands are an important part of the landscape in this region & & 636 & & \\
\hline Wetlands are important for plants and animals & & 628 & & -.425 \\
\hline Value for regulating ESs & & & -.803 & \\
\hline Value for provisioning ESs & & & .661 & \\
\hline $\begin{array}{l}\text { The restoration of wetlands limits the economic } \\
\text { growth of this region }\end{array}$ & -.511 & & .548 & \\
\hline The restoration of wetlands is a waste of valuable land & & & & .878 \\
\hline
\end{tabular}

significantly more important than did the residents. This suggests, that even though there may be conflicts between agriculture and biodiversity, being a farmer may promote a sense of stewardship, by which a strong connection with nature can be established.

The importance fishermen assigned to both recreation and food provision may indicate the limitations of treating ESs as separate entities. This problem has been discussed by several other scholars who indicate that ESs are often interlinked, and so it may be difficult for people to value them separately (Asah et al. 2014; Pröpper and Haupts 2014). The collection of food may be important for subsistence, but it may also contribute towards social cohesion. On a similar level, fishing as an economic activity may have multiple dimensions. Fishing provides income, but being out on the river may simultaneously have recreational aspects. Future ES research should focus on identifying the linkages between services and should acknowledge the myriad of ways with which people interact and relate with nature (Russell et al. 2013; Chan et al. 2016). Insight into how people connect with nature may provide us with the information necessary to strengthen this relationship, thereby promoting a nature conservation ethic.

\section{Linking ESs to Wetland Types}

Previous ES studies have often related socio-cultural values to ESs provided by a conservation area in general, not differentiating between specific ecosystems or ecosystem components (Castro et al. 2011; Tengberg et al. 2012; Allendorf and Yang 2013; Petrosillo et al. 2013; Sagie et al. 2013). Our results show that there is substantial difference between asking people for their awareness of ESs provided by Persina in general and the specific wetland types. Fifty-three percent of the respondents associated Persina with recreation, but less than $25 \%$ associated recreation with any of the wetland types. Such discrepancies were also found for tourism, environmental education, and the provision of food. This could mean that people associated different types of ecosystems and/or landscapes with these services. People may have associated the provision of food most with the agricultural fields present in Persina, or the Danube River itself, rather than with the wetlands within the park. It could however, also mean that people had a general perception of the landscapes in Persina, which did not completely correspond with the landscapes they saw on the photos.

Scholars studying landscape perceptions and preferences argue that people do not only form opinions about the landscape on the basis of the biophysical characteristics of that landscape, but also by 'mental images' (Lindemann-Matthies et al. 2010) or conceptions of what a landscape should look like (Terkenli 2001). Such mental images may be based on information, experiences, knowledge, institutions, and social networks. Comparing visual versus verbal techniques to capture forest landscape preferences, Tahvanainen et al. (2001) showed that preconceptions (i.e. mental images, about landscape management measures) did not match visual perceptions of these measures. The verbal assessment revealed a negative attitude towards small clear cutting in forests, while the visual assessment revealed that respondents thought small clear cutting enhanced the scenic value of forests. Visual illustration may thus be necessary for people to properly evaluate issues related to landscape and/or ecosystem management.

While landscape visualizations are commonly used in landscape preference studies (Kohsaka and Flitner 2004; Dramstad et al. 2006; Lange et al. 2008; Arnberger and Eder 2011; Barroso et al. 2012), they are less often used in ES studies. When the goal of the research is to elucidate general environmental values this does not have to be problematic, but in the case of ESs, researchers are often interested in assigned values, related to specific ecosystem and/or landscape types. PietrzykKaszyńska et al. (2012) suggested that people are more positive 

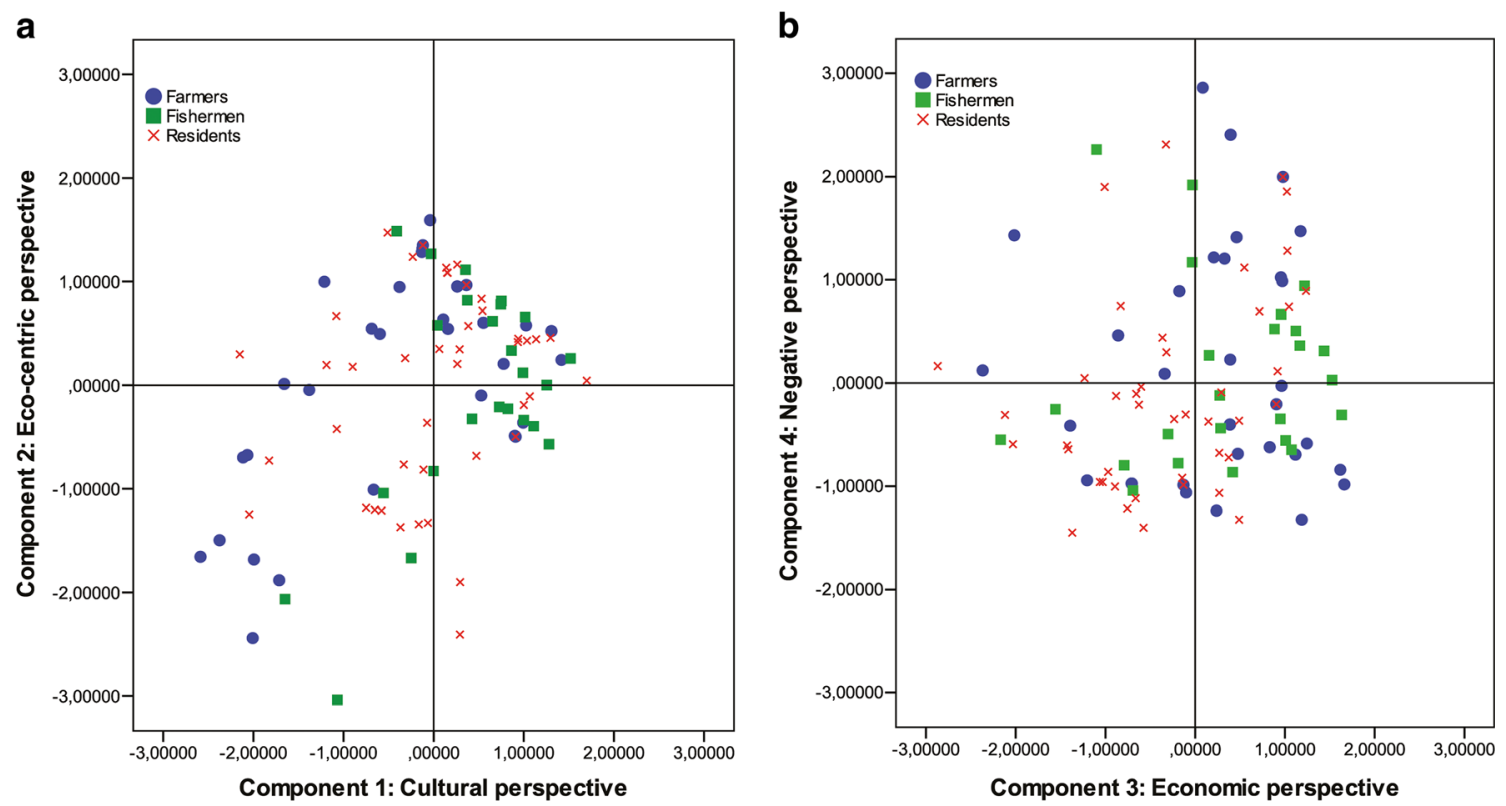

Fig. 5 Scatterplots of PCA scores for each respondent, categorized by the different user groups

towards 'nature' on a general level than they are towards specific landscapes. Our results confirm this notion because only $7 \%$ of the respondents had negative associations when asked about Persina in general, while more respondents had negative associations with wetland ecosystems. Twenty-two percent of the respondents had negative associations with marshes. The importance of targeted information about specific areas is invaluable when it comes to promoting public support and sustainable use of conservation areas.

\section{Understanding Attitudes Towards Wetland Restoration from Different Social Perspectives}

The four perspectives we identified demonstrate the different motivations people may have to support or oppose wetland restoration. These motivations can be explained by the way people perceive and interact with wetland ecosystems (Connely et al. 2002; Aggestam 2013). Farmers, who do not participate in recreation activities much, do not find the recreational value of wetland ecosystems very important and put most emphasis on the interplay between wetland restoration and economic benefits. Similar results have been found by Aggestam (2013), who reported that landowners highlighted the economic values of wetlands. Farmers are therefore likely to support wetland restoration when they can reap some of the benefits of the restored ecosystem services. This also means that when wetland restoration brings additional costs to local farmers, they may oppose to wetland restoration efforts. Fishermen on the other hand, who spend a lot of time near and on the river, recognize the multiple purposes of wetland restoration. As indicated by the importance they assigned to both provision of food and recreation, they may support wetland restoration because wetlands support their fisheries, e.g. by providing spawning areas for fish, but also because wetlands provide places where people can come at ease and connect with nature. In addition, residents in Persina may support wetland restoration out of concern for nature itself, not thinking about the benefits that humans obtain from wetland ecosystems.

Our findings are consistent with findings from other scholars who have identified underlying motivations for biodiversity and ES conservation. Studying local motivation for biodiversity conservation, Johansson (2005) identified three personal motives for biodiversity conservation: (a) consideration of human wellbeing and recreation, (b) human survival, and (c) respect for nature. Similarly, Opdam et al. (2015) put forward a sociocultural frame, a sustainability frame, and an economic frame. In ES research much effort has been spent on clarifying links between values for ESs and socio-demographic characteristics, while environmental value orientations may be more closely linked to the assigned importance to ESs.

Environmental value orientations underlie attitudes and normative beliefs (Vaske and Donnelly 1999) and can be found on a continuum between eco-centric and anthropocentric value orientations. Whereas anthropocentric value orientations stress the instrumental use of nature, corresponding to the cultural and economic perspective, eco-centric value orientations put more emphasis on the intrinsic value of nature, corresponding to the eco-centric perspective. The importance of environmental value orientations as underlying constructs for assigned values and attitudes has been put forward by several scholars in environmental psychology (Stern and Dietz 1994; Fulton et al. 1996; Vaske and Donnelly 1999; Kaltenborn and Bjerke 2002), but 
the link between environmental value orientations and values for ESs has been poorly studied.

The ES framework provides an anthropocentric frame for communicating the benefits of nature conservation by emphasizing the benefits provided by nature for human well-being. Opdam et al. (2015) argue, however, that even within the larger frame of the ES approach, the three ES categories, cultural, regulating and provisioning ESs, correspond with three different storylines. In their framework cultural ESs correspond with a socio-cultural frame that emphasizes cultural benefits, regulating ESs correspond with a sustainability frame that emphasizes benefits of ecological processes and provisioning ESs correspond with an economic frame that puts emphasis on the profits made from ecosystems. Our results partially confirm this conceptualization, although we have found two perspectives that did not correspond with values for ES categories.

The eco-centric perspective did not correlate with values for ESs. This may indicate that the anthropocentric character of the ES framework, with a focus on instrumental values, does not necessarily fit with eco-centric motivations for nature conservation (McCauley 2006; Norgaard 2010; Luck et al. 2012). ESs are commonly framed as the ecological functions that contribute to human well-being. A person with a strong eco-centric value orientation may not be willing to evaluate nature in this manner. Although several scholars have argued that socio-cultural ES assessments may allow for the integration of eco-centric values (Jax et al. 2013; Schröter et al. 2014), most ES valuation studies have not attempted to explicitly address eco-centric values.

The negative perspective did also not correlate with values for ESs. An explanation for this may be that people with a dominant negative attitude towards nature may put more emphasis on the costs of nature conservation instead of the benefits. One of the critiques on the ES framework is its positive framing, implying that all outcomes of ecological processes are desirable (McCauley 2006; Schröter et al. 2014). Our results show that $22 \%$ of the respondents had negative associations with marshes: respondents referred mostly to poor management, mosquitoes, and inaccessibility. This indicates that for a group of the respondents, wetland restoration may come with a certain cost that outweighs the associated benefits. For the success of wetland restoration efforts it is important to give attention to both the social costs and benefits of such projects. Awareness raising programs should therefore not only focus on the benefits provided by ecosystems, but also include strategies that deal with potential costs of wetland restoration.

\section{Fostering Public Support for Wetland Restoration}

In this study, most fishermen had positive values for both the cultural and economic perspective on ESs. Environmental perspectives therefore do not have to be mutually exclusive: every person is likely to have multiple perspectives, but in differing strengths (Kollmuss and Agyeman 2002). Even though people may adhere to multiple motivations for wetland restoration, when goals related to these motivations conflict, a choice has to be made. De Groot and Steg (2007) argue that 'although altruistic and environmental values may be correlated, they seem to be clearly differently related to environmental beliefs and intentions when altruistic and biospheric goals conflict' (p. 349). As an example: many respondents in this study highly valued biodiversity, but at the same time highly valued provisioning ESs. On a general level, people may be sympathetic towards the conservation of biodiversity, but when it comes to daily practices and actual environmental behavior, activities that conflict with biodiversity conservation still gain priority. This emphasizes the necessity of wetland restoration projects to identify synergies and trade-offs, making them better capable of dealing with both complementary and competing goals. As expressed by McShane et al. (2011), win-win scenarios are scarce and nature conservation involves hard choices, which need to be made explicit.

To foster support for wetland restoration and promote sustainable use wetland restoration areas, a targeted approach is necessary. Raising awareness can be a useful strategy to foster public support for wetland restoration, but different groups of people may require different kinds of information. Reflecting upon the theory of Festinger (1957), Kollmuss and Agyeman (2002) put forward the idea that people may show a resistance against non-conforming information, meaning that 'information that supports our existing values and mental frameworks is readily accepted, whereas information that contradicts or undermines our beliefs is avoided or not perceived at all' ( $p$. 254). This means that the benefits and losses of wetland restoration should be "framed" in ways that resonate with the public (Groffman et al. 2010). The results from this paper suggest that gaining insight into how people interact with and perceive ecosystems is important to understand what aspects of ecosystem conservation and/or restoration people put most emphasis on. The perspectives we identified provide guidance for targeted information that can be used by local environmental organizations to reach a diverse set of stakeholders.

In addition, careful thought should be put into crafting opportunities to engage with local users about wetland restoration (Varner 2014). It is important to get more interested in our audience beyond treating them as 'recipients for expert knowledge' (Salmon et al. 2015), as most people do not learn about science through formal education but through informal sources (Groffman et al. 2010). When forming ideas and attitudes about ecological restoration, people often do not rely on logical arguments and reasoning, but on knowledge they draw from experiences, e.g. by being in nature or by talking with others, and/or emotions (Brody 2005; Fazey et al. 2013). Having local stakeholders actively 
participate in ecological restoration efforts, for example by assisting in environmental monitoring, may positively affect the way local users think about ecological restoration (Conrad and Hilchey 2011). In addition, scientists should make use of informal and non-scientific events to exchange ideas about the benefits and costs of ecological restoration with the public (Sayer et al. 2014). By actively engaging with local users, scientists and environmental managers can foster support for wetland restoration projects, which is likely to increase the success of wetland restoration and conservation (Cooke et al. 2013).

Acknowledgments We would like to thank Emilia Petkova, Vasilka Petrova, Zlatko Kamenarov and Channa Lozeva for their assistance with the interviews. This work was supported by the European Union Seventh Framework Programme (FP7/2007-2013) under grant agreement no. 303 393 "OPERAs".

\section{Appendix}

Table 5 Characteristics of the sample

\begin{tabular}{|c|c|c|}
\hline \multicolumn{2}{|c|}{ Socio-economic variables } & \multirow{2}{*}{$\begin{array}{l}\begin{array}{l}\text { Respondents } \\
(n=102)^{*}\end{array} \\
90\end{array}$} \\
\hline Grew up in Persi & & \\
\hline \multirow[t]{2}{*}{ Gender $(\%)$} & male & 66.7 \\
\hline & female & 33.3 \\
\hline Age $(\mathrm{M}, S D)$ & $45.9(14.4)$ & \\
\hline \multirow[t]{4}{*}{ Education (\%) } & Primary & 13.7 \\
\hline & Secondary & 66.7 \\
\hline & $\begin{array}{l}\text { Medium } \\
\text { professional } \\
\text { formation }\end{array}$ & 9.8 \\
\hline & University & 9.8 \\
\hline \multirow{6}{*}{$\begin{array}{l}\text { Occupation } \\
(\%)\end{array}$} & Farmer & 33.3 \\
\hline & Fisherman & 24.5 \\
\hline & Business owner & 4.9 \\
\hline & Other & 16.7 \\
\hline & Retired & 10.8 \\
\hline & Unemployed & 9.8 \\
\hline \multirow{6}{*}{$\begin{array}{l}\text { Monthly net } \\
\text { household } \\
\text { income }(\%)\end{array}$} & no income & 1.0 \\
\hline & $0-50$ euro & 3.9 \\
\hline & 51-255 euro & 46.1 \\
\hline & $256-510$ euro & 40.1 \\
\hline & 511-1022 euro & 6.9 \\
\hline & $>1022$ euro & 2.0 \\
\hline $\begin{array}{l}\text { Household size } \\
\qquad(\mathrm{M}, S D)\end{array}$ & $4(2.8)$ & \\
\hline
\end{tabular}

Open Access This article is distributed under the terms of the Creative Commons Attribution 4.0 International License (http:// creativecommons.org/licenses/by/4.0/), which permits unrestricted use, distribution, and reproduction in any medium, provided you give appropriate credit to the original author(s) and the source, provide a link to the Creative Commons license, and indicate if changes were made.

\section{References}

Adams VM, Pressey RL, Naidoo R (2010) Opportunity costs: Who really pays for conservation? Biol Conserv 143:439-448. doi:10.1016/j. biocon.2009.11.011

Agbenyega O, Burgess PJ, Cook M, Morris J (2009) Application of an ecosystem function framework to perceptions of community woodlands. Land Use Policy 26:551-557. doi:10.1016/j.landusepol. 2008.08.011

Aggestam F (2013) Wetland restoration and the involvement of stakeholders: an analysis based on value-perspectives. Landsc Res 39: 680-697. doi:10.1080/01426397.2013.819076

Allendorf TD, Yang J (2013) The role of ecosystem services in parkpeople relationships: the case of gaoligongshan nature reserve in southwest China. Biol Conserv 167:187-193. doi:10.1016/j. biocon.2013.08.013

Arnberger A, Eder R (2011) Exploring the heterogeneity of rural landscape preferences: an image-based latent class approach. Landsc Res 36:19-40. doi:10.1080/01426397.2010.536204

Asah ST, Guerry AD, Blahna DJ, Lawler JJ (2014) Perception, acquisition and use of ecosystem services: human behavior, and ecosystem management and policy implications. Eco Ser. doi:10.1016/j.ecoser. 2014.08.003

Barroso FL, Pinto-Correia T, Ramos IL et al (2012) Dealing with landscape fuzziness in user preference studies: photo-based questionnaires in the Mediterranean context. Landsc Urban Plan 104:329 342

Brockington D, Wilkie D (2015) Protected areas and poverty. Philos Trans R Soc Lond B Biol Sci 370:20140271. doi:10.1098/rstb. 2014.0271

Brody M (2005) Learning in nature. Environ Educ Res 11:603-621. doi: 10.1080/13504620500169809

Calvet-Mir L, Gómez-Baggethun E, Reyes-García V (2012) Beyond food production: ecosystem services provided by home gardens. A case study in vall fosca, Catalan Pyrenees, northeastern Spain. Ecol Econ 74:153-160. doi:10.1016/j.ecolecon.2011.12.011

Castro AJ, Martín-López B, García-LLorente M et al (2011) Social preferences regarding the delivery of ecosystem services in a semiarid Mediterranean region. J Arid Environ 75:1201-1208. doi:10.1016/j. jaridenv.2011.05.013

Chan KMA, Balvanera P, Benessaiah K et al (2016) Opinion: Why protect nature? rethinking values and the environment. Proc Natl Acad Sci 113:1462-1465. doi:10.1073/pnas.1525002113

Č́źǩková H, Květ J, Comín FA et al (2011) Actual state of European wetlands and their possible future in the context of global climate change. Aquat Sci 75:3-26. doi:10.1007/ s00027-011-0233-4

Comberti C, Thornton TF, Wylliede Echeverria V, Patterson T (2015) Ecosystem services or services to ecosystems? valuing cultivation and reciprocal relationships between humans and ecosystems. Glob Environ Chang 34:247-262. doi:10.1016/j. gloenvcha.2015.07.007

Connely NA, Knuth BA, Kay DL (2002) Public support for ecosystem restoration in the Hudson River Valley, USA. Environ Manag 29: 467-476. doi:10.1007/s00267-001-0033-Z 
Conrad CC, Hilchey KG (2011) A review of citizen science and community-based environmental monitoring: issues and opportunities. Environ Monit Assess 176:273-291. doi:10.1007/s10661-010$1582-5$

Cooke SJ, Lapointe NWR, Martins EG et al (2013) Failure to engage the public in issues related to inland fishes and fisheries: strategies for building public and political will to promote meaningful conservationa. J Fish Biol 83:997-1018. doi:10.1111/jfb.12222

Costanza R, d'Arge R, de Groot R et al (1997) The value of the world's ecosystem services and natural capital. Nature 387:253-260. doi:10. $1038 / 387253 \mathrm{a} 0$

Daily GC (1997) Nature's services: societal dependence on natural ecosystems. Island Press Washington DC, Washington

Daw T, Brown K, Rosendo S, Pomeroy R (2011) Applying the ecosystem services concept to poverty alleviation: the need to disaggregate human well-being. Environ Conserv 38:370-379. doi:10.1017/ S0376892911000506

de Groot JIM, Steg L (2007) Value orientations to explain beliefs related to environmental significant behavior: How to measure egoistic, altruistic, and biospheric value orientations. Environ Behav 40: 330-354. doi:10.1177/0013916506297831

de Groot RS, Wilson MA, Boumans RM (2002) A typology for the classification, description and valuation of ecosystem functions, goods and services. Ecol Econ 41:393-408. doi:10.1016/S09218009(02)00089-7

de Groot R, Fisher B, Christie M, et al. (2010) Integrating the ecological and economic dimensions in biodiversity and ecosystem service valuation. Econ. Ecosyst. Biodivers. Ecol. Econ. Found

de Groot R, Brander L, van der Ploeg S et al (2012) Global estimates of the value of ecosystems and their services in monetary units. Ecos Ser 1:50-61. doi:10.1016/j.ecoser.2012.07.005

Dobbie M, Green R (2013) Public perceptions of freshwater wetlands in Victoria, Australia. Landsc Urban Plan 110:143-154. doi:10.1016/j. landurbplan.2012.11.003

Dramstad WE, Tveit MS, Fjellstad WJ, Fry GLA (2006) Relationships between visual landscape preferences and map-based indicators of landscape structure. Landsc Urban Plan 78:465-474. doi:10.1016/j. landurbplan.2005.12.006

Ebert S, Hulea O, Strobel D (2009) Floodplain restoration along the lower Danube: a climate change adaptation case study. Climate Dev 1: 212-219. doi:10.3763/cdev.2009.0022

Fazey I, Evely AC, Reed MS et al (2013) Knowledge exchange: a review and research agenda for environmental management. Environ Conserv 40:19-36. doi:10.1017/S037689291200029X

Festinger L (1957) A theory of cognitive dissonance. Stanford University Press, Stanford

Fulton DC, Manfredo MJ, Lipscomb J (1996) Wildlife value orientations: a conceptual and measurement approach. Hum Dimens Wildl 1:24 47. doi:10.1080/10871209609359060

Grêt-Regamey A, Celio E, Klein TM, Wissen Hayek U (2013) Understanding ecosystem services trade-offs with interactive procedural modeling for sustainable urban planning. Landsc Urban Plan 109:107-116. doi:10.1016/j.landurbplan.2012.10.011

Groffman PM, Stylinski C, Nisbet MC et al (2010) Restarting the conversation: challenges at the interface between ecology and society. Front Ecol Environ 8:284-291. doi:10.1890/090160

Gumiero B, Mant J, Hein T et al (2013) Linking the restoration of rivers and riparian zones/wetlands in Europe: sharing knowledge through case studies. Ecol Eng 56:36-50

Haines-Young RH, Potschin MB (2010) The links between biodiversity, ecosystem services and human well-being. Ecosyst. Ecol. a new Synth

Hartter J (2010) Resource use and ecosystem services in a forest park landscape. Soc Nat Resour 23:207-223. doi:10.1080/ 08941920903360372
Hulea O, Ebert S, Strobel D (2009) Floodplain restoration along the lower Danube: a climate change adaptation case study IOP conference series. Earth Environ Sci 6:402002. doi:10.1088/1755-1307/6/40/ 402002

Jax K, Barton DN, Chan KMA et al (2013) Ecosystem services and ethics. Ecol Econ 93:260-268. doi:10.1016/j.ecolecon.2013.06.008

Johansson M (2005) Local people's motives for biodiversity conservation. Hogrefe \& Huber Publishers, Cambridge

Junk WJ, An S, Finlayson CM et al (2012) Current state of knowledge regarding the world's wetlands and their future under global climate change: a synthesis. Aquat Sci 75:151-167. doi:10.1007/s00027012-0278-Z

Kaltenborn BP, Bjerke T (2002) Associations between environmental value orientations and landscape preferences. Landsc Urban Plan 59:1-11. doi:10.1016/S0169-2046(01)00243-2

Kari S, Korhonen-Kurki K (2013) Framing local outcomes of biodiversity conservation through ecosystem services: a case study from ranomafana, Madagascar. Ecos Ser 3:e32-e39. doi:10.1016/j. ecoser.2012.12.003

Kohsaka R, Flitner M (2004) Exploring forest aesthetics using forestry photo contests: case studies examining Japanese and German public preferences. Forest Policy Econ 6:289-299. doi:10.1016/j.forpol. 2004.03.016

Kollmuss A, Agyeman J (2002) Mind the Gap: Why do people act environmentally and what are the barriers to pro- environmental behavior? 37-41.

Lange E, Hehl-Lange S, Brewer MJ (2008) Scenario-visualization for the assessment of perceived green space qualities at the urban-rural fringe. J Environ Manag 89:245-56. doi:10.1016/j.jenvman.2007. 01.061

Lindemann-Matthies P, Junge X, Matthies D (2010) The influence of plant diversity on people's perception and aesthetic appreciation of grassland vegetation. Biol Conserv 143:195-202. doi:10.1016/j. biocon.2009.10.003

Luck GW, Chan KMA, Eser U et al (2012) Ethical considerations in onground applications of the ecosystem services concept. Bioscience 62:1020-1029. doi:10.1525/bio.2012.62.12.4

MA (Millenium Ecosystem Assessment) (2005) Ecosystems and human well-being - synthesis. Island Press, Washington

McCauley DJ (2006) Selling out on nature. Nature 443:27-8. doi:10. $1038 / 443027 \mathrm{a}$

McShane TO, Hirsch PD, Trung TC et al (2011) Hard choices: making trade-offs between biodiversity conservation and human well-being. Biol Conserv 144:966-972. doi:10.1016/j.biocon.2010.04.038

Meindl CF (2000) Past perception of the great American wetland: Florida's everglades during the early twentieth century. Environ Hist 5:378-395

Minteer BA, Miller TR (2011) The New conservation debate: ethical foundations, strategic trade-offs, and policy opportunities. Biol Conserv 144:945-947. doi:10.1016/j.biocon.2010.07.027

Nassauer JI (2004) Monitoring the success of metropolitan wetland restorations: cultural sustainability and ecological function. Wetlands 24:756-765. doi:10.1672/0277-5212(2004)024[0756:MTSOMW] 2.0. $\mathrm{CO} ; 2$

Naughton-Treves L, Holland MB, Brandon K (2005) The role of protected areas in conserving biodiversity and sustaining local livelihoods. Annu Rev Environ Resour 30:219-252. doi:10.1146/ annurev.energy.30.050504.164507

Norgaard RB (2010) Ecosystem services: from eye-opening metaphor to complexity blinder. Ecol Econ 69:1219-1227. doi:10.1016/j. ecolecon.2009.11.009

Opdam P, Coninx I, Dewulf A et al (2015) Framing ecosystem services: affecting behaviour of actors in collaborative landscape planning? Land Use Policy 46:223-231. doi:10.1016/j.landusepol.2015.02. 008 
Petrosillo I, Costanza R, Aretano R et al (2013) The use of subjective indicators to assess how natural and social capital support residents' quality of life in a small volcanic island. Ecol Indic 24:609-620. doi: 10.1016/j.ecolind.2012.08.021

Pietrzyk-Kaszyńska A, Cent J, Grodzińska-Jurczak M, Szymańska M (2012) Factors influencing perception of protected areas - the case of natura 2000 in polish Carpathian communities. J Nat Conserv 20: 284-292. doi:10.1016/j.jnc.2012.05.005

Pröpper M, Haupts F (2014) The culturality of ecosystem services. Emphasizing process and transformation. Ecol Econ 108:28-35. doi:10.1016/j.ecolecon.2014.09.023

Raymond CM, Singh G, Benessaiah K et al (2013) Ecosystem services and beyond. Bioscience 63:536-546. doi:10.1525/bio.2013.63.7.7

Rönnbäck P, Crona B, Ingwall L (2007) The return of ecosystem goods and services in replanted mangrove forests: perspectives from local communities in Kenya. Environ Conserv 34:313-324. doi:10.1017/ S0376892907004225

Russell R, Guerry AD, Balvanera P, et al. (2013) Humans and Nature: How Knowing and Experiencing Nature Affect Well-Being. Annual Review of Environment and Resources. 10.1146/annurev-environ012312-110838

Sagie H, Morris A, Rofè Y et al (2013) Cross-cultural perceptions of ecosystem services: a social inquiry on both sides of the IsraeliJordanian border of the Southern Arava Valley Desert. J Arid Environ 97:38-48. doi:10.1016/j.jaridenv.2013.05.007

Salmon RA, Priestley RK, Goven J (2015) The reflexive scientist: an approach to transforming public engagement. J Environ Stud Sci. doi: $10.1007 / \mathrm{s} 13412-015-0274-4$

Sayer EJ, Featherstone HC, Gosling WD (2014) Sex \& bugs \& rock'n roll-getting creative about public engagement. Trends Ecol Evol 29: 65-7. doi:10.1016/j.tree.2013.12.008

Schneider E (2010) Floodplain Restoration of Large European Rivers with Examples from the Rhine and the Danube. In: Eiseltová $M$ (ed) Restoration of Lakes, Streams, Floodplains, and Bogs in Europe. Springer Netherlands, pp 185-223

Scholte SSK, van Teeffelen AJA, Verburg PH (2015) Integrating sociocultural perspectives into ecosystem service valuation: a review of concepts and methods. Ecol Econ 114:67-78. doi:10.1016/j. ecolecon.2015.03.007

Schröter M, van der Zanden EH, van Oudenhoven APE, et al. (2014) Ecosystem services as a contested concept: a synthesis of critique and counter-arguments. Conservation Letters 7:n/a-n/a. 10.1111/ conl.12091

Secretariat RC (2010) Designating ramsar sites: strategic framework and guidelines for the future development of the list of wetland for international importance. Gland, Switzerland

Setten G, Stenseke M, Moen J (2012) Ecosystem services and landscape management: three challenges and one plea. Int J Biodivers Scie Ecos Serv Manag 8:305-312. doi:10.1080/21513732.2012.722127

Southworth J, Nagendra H, Munroe DK (2006) Introduction to the special issue: Are parks working? exploring human-environment tradeoffs in protected area conservation. Appl Geogr 26:87-95. doi:10.1016/j.apgeog.2005.11.001

Stern PC, Dietz T (1994) The value basis of environmental concern. J Soc Issues 50:65-84. doi:10.1111/j.1540-4560.1994.tb02420.x

Tahvanainen L, Tyrväinen L, Ihalainen M et al (2001) Forest management and public perceptions - visual versus verbal information. Landsc Urban Plan 53:53-70. doi:10.1016/S0169-2046(00)00137-7

Tengberg A, Fredholm S, Eliasson I et al (2012) Cultural ecosystem services provided by landscapes: assessment of heritage values and identity. Ecos Serv 2:14-26. doi:10.1016/j.ecoser.2012.07.006

Terkenli TS (2001) Towards a theory of the landscape: the Aegean landscape as a cultural image. Landsc Urban Plan 57:197-208. doi:10. 1016/S0169-2046(01)00204-3

van Asselen S, Verburg PH, Vermaat JE, Janse JH (2013) Drivers of wetland conversion: a global meta-analysis. PLoS One 8, e81292. doi:10.1371/journal.pone.0081292

Varner J (2014) Scientific outreach: toward effective public engagement with biological science. Bioscience 64:333-340. doi:10.1093/ biosci/biu021

Vaske JJ, Donnelly MP (1999) A value-attitude-behavior model predicting wildland preservation voting intentions. Soc Nat Resour 12:523-537. doi:10.1080/089419299279425

Verhoeven JTA (2014) Wetlands in Europe: perspectives for restoration of a lost paradise. Ecol Eng 6:6-9

WWF (2010). Lower Green Danube Corridor. Accessed online at http:// assets.panda.org/downloads/wwf ldgc.pdf

Zedler JB, Kercher S (2005) Wetland resources: status, trends, ecosystem services, and restorability. Annu Rev Environ Resour 30:39-74. doi: 10.1146/annurev.energy.30.050504.144248 